\title{
Food supplementation reduces post-release dispersal during simulated translocation of the Endangered pygmy bluetongue lizard Tiliqua adelaidensis
}

\author{
Mehregan Ebrahimi*, C. Michael Bull \\ School of Biological Sciences, Flinders University, GPO Box 2100, Adelaide, South Australia 5001, Australia
}

\begin{abstract}
Translocation is among several tools available to conservation managers, either to augment existing populations, or to establish populations in previously occupied habitat, or in habitat identified as suitable for the future persistence of the species. Translocated reptiles do not always become established at the release site. We simulated a translocation site for an Endangered Australian skink, the pygmy bluetongue lizard Tiliqua adelaidensis, to investigate whether adding food would encourage released individuals to disperse less. We provided artificial burrows in a central release area within circular cages and found that lizards were more likely to remain in a burrow, spent less time exposed on the ground surface and were less likely to move out of the central area when food was provided. These modified behaviours are likely to encourage translocation success if lizards with added food expose themselves less frequently to predators, and if fewer of those lizards disperse away from the translocation site in the early days after release. We suggest that the provision of supplementary food will be an important component of any translocation programme for this lizard.
\end{abstract}

KEY WORDS: Supplementary food · Translocation · Tiliqua adelaidensis · Conservation

\section{INTRODUCTION}

In conservation management, translocation, or assisted colonisation, is the intentional movement of individuals from one area to another. Translocation can be used to augment existing populations and to reintroduce a species to currently unoccupied sites within its former range, or to assist colonisation of sites outside of its historic range that are considered suitable to sustain future populations. While there is debate about the impact on other members of the ecological community where translocations are outside the historic range, translocation is still considered an important tool for conservation management (IUCN 1987, 1998, Ebenhard 1995, Hodder \& Bullock 1997, Tenhumberg et al. 2004, Rout et al. 2005).
Translocation success, measured by persistence and growth of the translocated population (Seddon 1999, van Heezik et al. 2009), is not always high (Fischer \& Lindenmayer 2000, Germano \& Bishop 2009). There are 3 major problems. One is that translocated individuals are likely to disperse from the release site as a result of locally high population density if many individuals are released in the same area, competition and predation from the resident fauna, or inadequate resource quality and availability (Dodd \& Seigel 1991, Armstrong \& McLean 1995, van Heezik et al. 2009). A second is that translocated individuals must become familiar with local food and shelter resources, and overcome pressure from resident conspecific and other competitors for those resources. A third is that hungry individuals might increase activity levels, exposing them to higher predation risk 
(McNamara 1987, Werner \& Anholt 1993). As a result of the second and third problems, even those translocated individuals that do not disperse from the release site may still lose body condition, or fail to reproduce successfully in their new habitat (Wolf et al. 1996, Towns \& Ferreira 2001, Armstrong et al. 2007). For instance, slow-worms Anguis fragilis that survived translocation and remained at the site often had poorer body condition than long-term residents (Platenberg \& Griffiths 1999).

Translocations may be more successful if the impact of 1 or more of these factors is reduced at the release site (Hodder \& Bullock 1997, Armstrong \& Perrott 2000), and if positive factors are enhanced to encourage individuals to stay at a new site long enough to become established. For example, as food availability influences all levels of population and community dynamics (Boutin 1990, Anholt \& Werner 1995), supplementary feeding may be used as a conservation tool to prevent population decline caused by natural food shortages. For instance Elliott et al. (2001) found that supplementary feeding increased survival in chicks of the endangered New Zealand kakapo Strigops habroptilus, and López-Bao et al. (2008) showed that endangered lynx were less likely to disperse from population sites when natural food levels were low, if supplementary food was added. However, supplementary feeding did not improve breeding success, clutch size or population density of an endangered eagle (Simmons 1993) or reproductive success of a pheasant (Hoodless et al. 1999). Additionally, there is concern about the broader impacts of such major perturbations to natural systems both to the target species (Clout et al. 2002) and to other components of the ecological community (Robb et al. 2008).

In translocation programmes, food supplementation has already been used to reduce dispersal and home range (Boutin 1990, López-Bao et al. 2008), maintain body condition (Bright \& Morris 1994) and increase reproduction (Castro et al. 2003, Schoech et al. 2008) of translocated individuals, again with variable success (Armstrong \& Perrott 2000).

Here we investigated whether adding supplementary food would reduce short-term dispersal in simulated translocation releases of an Endangered Australian scincid lizard, the pygmy bluetongue lizard Tiliqua adelaidensis. This species is now restricted to a few isolated fragments of native grassland in northcentral South Australia, where they occupy narrow vertical burrows, constructed by spiders. They take refuge in these burrows and use the entrances for basking and as ambush sites for passing invertebrate prey.
In natural populations, pygmy bluetongue lizards (average snout-to-vent length of $95 \mathrm{~mm}$ ) spend most of their time associated with an individual burrow (Milne et al. 2003b), rarely leaving it, and even reducing their aggressive burrow defense to a distance of less than $20 \mathrm{~cm}$ from the burrow entrance, which does not require them to completely emerge (Fenner \& Bull 2011a). Normal movements beyond the burrow are for prey capture (Milne et al. 2003b) or defecation. For instance, they deposit scats at distances between 25 and $70 \mathrm{~cm}$ from their burrows (Fenner \& Bull 2010), although males make occasional longer moves searching for female mates in spring (Fenner \& Bull 2009). Also, there is occasional dispersal within the population to seek new burrows (Fellows et al. 2009, Fenner \& Bull 2011b). Out of their burrows, lizards are more vulnerable to predation from birds and snakes (Hutchinson et al. 1994, Milne et al. 2003b, Fenner et al. 2008a,b), as indicated by the high incidence of tail damage (Fenner et al. 2006). For lizards seeking a new burrow, there are additional exposure risks if no suitable alternative burrow is available, or if dispersal takes them out of suitable habitat.

Although existing populations appear secure in the short term, changes in land use and climate pose longer-term threats to this species. Translocation of pygmy bluetongue lizards to additional sites within their historical range is a management option, and will have a greater chance of success if translocated individuals can be encouraged to remain where they are released. Dispersal away from the release site may remove lizards from the various management arrangements designed to promote their well-being.

Our study aimed to explore the influence of food supplementation on those behaviours of the lizard that might be related to whether it tended to stay at, or disperse from, the translocation site. This study was not intended to determine whether adding supplementary food would enhance the overall success of a translocation.

\section{MATERIALS AND METHODS}

Eight male and 8 female pygmy bluetongue lizards were captured from 2 populations near Burra (4 males and 4 females from each), South Australia $\left(33^{\circ} 42^{\prime} \mathrm{S}, 138^{\circ} 56^{\prime} \mathrm{E}\right)$ in September 2009, and transported to Monarto Zoo $\left(35^{\circ} 06^{\prime} \mathrm{S}, 1^{\circ}\right.$ $\left.09^{\prime} \mathrm{E}\right)$. They were individually held for $3 \mathrm{~d}$ in plastic boxes $(52.5 \times 38 \times 31 \mathrm{~cm})$, each fed 3 mealworms on the first day, and then left unfed for $2 \mathrm{~d}$ prior to the experiment. 
For the experiment, 4 circular cages (15 m diameter) were built at Monarto. They had $1 \mathrm{~m}$ high galvanised iron walls and bird-proof wire roofs and were located in a line, about $5 \mathrm{~m}$ apart. Each cage included a central $4 \mathrm{~m}$ diameter circular area, lightly vegetated with annual grasses, but cut to ground level before the start of the experiment, representing the translocated habitat. Surrounding that was a $5 \mathrm{~m}$ wide ring of lightly tilled, bare ground representing unsuitable habitat, and then an untilled margin, $0.5 \mathrm{~m}$ wide, around the inner perimeter of the cage (Fig. 1). We constructed artificial burrows for the lizards from $30 \mathrm{~cm}$ lengths of $3 \mathrm{~cm}$ diameter wooden dowling, with a drilled-out centre (2 $\mathrm{cm}$ internal diameter), hammered into the ground until the entrance was flush with the ground surface. Pygmy bluetongue lizards in natural populations accept artificial burrows of similar design (Milne et al. 2003a, Souter et al. 2004, Ebrahimi et al. 2012). We placed 41 artificial burrows in the central area of each cage, 1 in the centre of the area and the others in 3 concentric rings of 8, 16 and 16 burrows, spaced $65 \mathrm{~cm}$ apart, with individual burrows within each ring $65 \mathrm{~cm}$ apart in the inner ring, and $75 \mathrm{~cm}$ apart in the outer ring (Fig. 1). No burrows were placed in the area of unsuitable habitat, but 30 burrows were evenly spaced around the perimeter ring (Fig. 1).

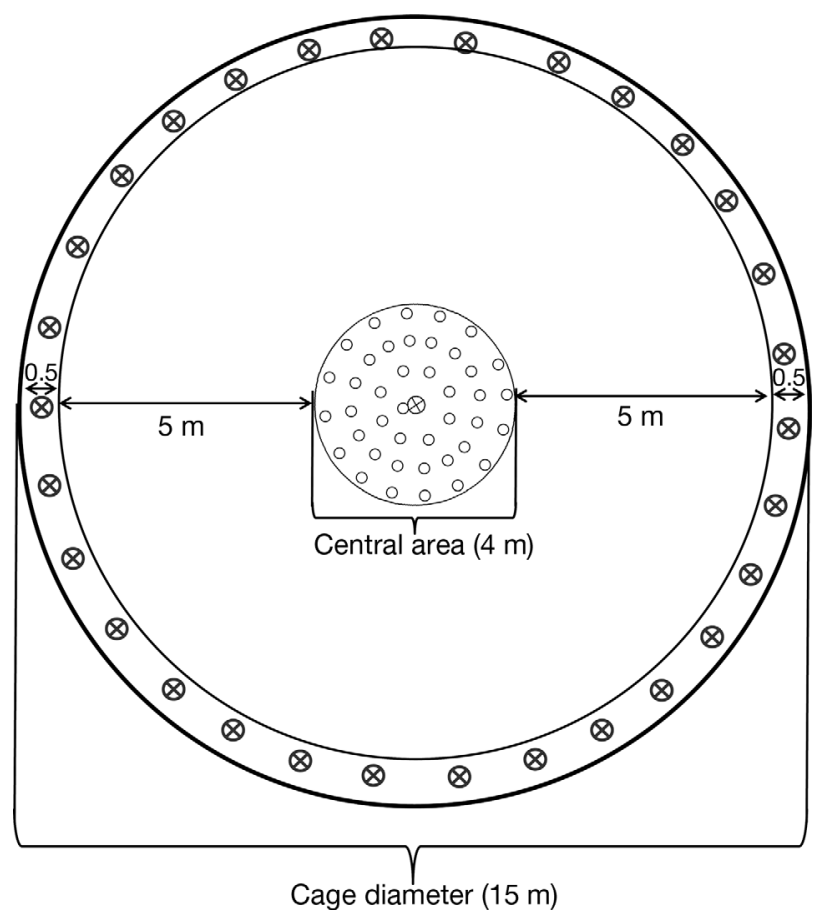

Fig. 1. Experimental cage design, showing the locations of the artificial burrows within the central and peripheral (marginal) areas. $O$ represents artificial burrows in the central area; $\otimes$ represents burrows in the marginal area
The combined field of view of 4 surveillance cameras (Longse: LICS23Hf, $3.5 \mathrm{~mm}$ lens) mounted above each cage covered the entire ground surface in the central area only. The cameras recorded all lizard activity in that area during daylight hours from 07:00 to 18:00 h on each day of the experiment, on a 16-channel h.264 DVR (ESW26), powered by 4 batteries $(12 \mathrm{~V})$. One digital thermometer at each end of the line of cages recorded continuous shade temperature each day, and from these we derived daily minimum, maximum and average temperatures. We also used temperature recordings from a weather station at Pallamana Aerodrome $\left(35.07^{\circ} \mathrm{S}, 139.23^{\circ} \mathrm{E}\right), 10 \mathrm{~km}$ from Monarto Zoo to confirm the site readings.

Within each of the 4 cages, we released 2 male and 2 female lizards into separate central burrows at 07:00 h on 15 November 2009 and confined them to the central area for the rest of that day with a temporary circular wall of $20 \mathrm{~cm}$ high black plastic. These walls were removed before lizard activity started on the second day.

To determine the influence of food availability on lizard movements after release, the experimental cages were divided into 2 treatments, fed and unfed. Lizards in 2 of the cages were fed daily for $7 \mathrm{~d}$, while those in the other 2 cages were unfed. All lizards were then left unfed and undisturbed for $2 \mathrm{~d}$ before the experiment continued with the fed and unfed cage treatments reversed in the following $7 \mathrm{~d}$. Between 12:00 and 13:00 $\mathrm{h}$ on the first day, and on each of the next $6 \mathrm{~d}$, we fed each lizard in 2 of the cages with 3 meal worms (average mass $=7.7 \mathrm{~g}$ ). We placed 1 meal worm at the entrance of each occupied burrow after the previous meal worm had been consumed. Lizards in the other 2 unfed control cages received no supplementary food over this period, but the same time was spent by an observer around each occupied burrow. On every feeding day, the lizards consumed all 3 offered prey items with no apparent change to the rate of consumption, suggesting that the lizards did not become habituated to the feeding regime, or vary in satiation levels during it. From the video recordings, only 3 cases of lizards feeding on incidental invertebrate prey were observed during the experiment. One was in a cage receiving supplementary food, and 2 were in unfed cages.

Lizard behavioural parameters were derived from the video recordings, and data were analysed from the last $6 \mathrm{~d}$ (Days 2 to 7 ) of each $7 \mathrm{~d}$ feeding period. On Day 1 of the first week, the lizards were still confined to the central area by the plastic wall, and we wanted to use a comparable period of days in the sec- 
ond week. We tested whether adding food altered lizard behaviour using repeated-measures analysis of variance (ANOVA) with supplementary food (added or not added), and day of feeding period (Days 2 to 7 ) as within-subjects factors, and the order of presentation (food then no food, or no food then food) as a between-subjects factor. We used the GreenhouseGeisser correction where data were non-spherical. The effect of temperature on lizard behaviour was examined by Pearson correlation. The parameters that we analysed were activity time $\left(\mathrm{h} \mathrm{d}^{-1}\right)$, total activity $\left(\right.$ no. $\left.\mathrm{d}^{-1}\right)$, number of movements $\left(\right.$ no. $\left.\mathrm{d}^{-1}\right)$, number of burrow changes (no. $\mathrm{d}^{-1}$ ), average basking time $\left(\operatorname{min~}^{-1}\right)$ and number of fights (no. $\mathrm{d}^{-1}$ ).

Daily activity time was defined as the time from when the head of a lizard first emerged from the burrow entrance to when the lizard retreated into its burrow for the last time on that day. In 12 cases (out of 192 lizard-days of filming) a lizard was in a burrow in the marginal area, at the perimeter of the cage, at the start or the end of filming. In those cases we could not determine the total activity time because the marginal area was not filmed. We defined total activity as the number of activity events for each lizard for each day. An activity event occurred when a lizard emerged from its burrow, either partially to bask at the burrow entrance or fully to bask or move around. An event started when the head of a lizard first emerged from its burrow, and finished when the lizard completely re-entered the same or another burrow. Among activity events, we defined those when the lizard fully emerged from its burrow as movements. We counted the total number of movements for each lizard for each day. One movement was from when a lizard fully emerged from a burrow to when it entered the same or a new burrow. During movements, lizards walked around the cage area, basked, foraged, defecated or sought a new burrow. Among the movements, we recorded the number of times each lizard changed burrows within the central area each day. Burrows in the marginal area were not in the field of view of the cameras. However, we recorded whether lizards had moved into a marginal burrow, by undertaking 3 visual inspections each day: before filming started, after it had finished, and in the middle of the day, when supplementary food was added to the treatment cages. This may have underestimated the actual use of marginal area burrows, but the level of error should have been comparable across cages and across experimental treatments, allowing unbiased analyses of this parameter. The average daily bask- ing time $\left(\operatorname{min~} \mathrm{h}^{-1}\right)$ was calculated for each lizard from the total time it spent basking at its burrow entrance in the central area, divided by the total filming hours when we knew the lizard was in the central area. We did not include the rare (and brief) cases when a lizard basked while away from its burrow entrance.

When a lizard approached another, there was always an agonistic interaction, involving either a brief scuffle, or 1 lizard running away from the other. We defined all of these as fights, and counted the number of fights lizard ${ }^{-1} \mathrm{~d}^{-1}$.

For activity time, number of activity events and number of movements, we were unable to get complete data from those lizards that left the central area during a day. In our analyses of those parameters, we used each cage as a replicate, with the mean values only from fully documented lizards in the cage on that day. For the other behavioural parameters, we used data from individual lizards as replicates.

\section{RESULTS}

We recorded 2298 activity events by the 16 lizards during $12 \mathrm{~d}$ of filming. Of those, 1352 cases were of lizards partially emerging from their burrow to bask at the burrow entrance before re-entering the same burrow, and 708 cases were of lizards that completely emerged, to move around before returning to the same burrow. In 238 cases, lizards completely emerged and moved to a new burrow. Of those, 182 moved to a new burrow in the central area, and 56 moved to a new burrow in the marginal area. Among the 946 cases of lizards that had completely emerged, there were 45 cases where 2 lizards displayed aggression towards each other, with 12 of the 16 lizards displaying aggression to another lizard at least once.

\section{Effect of ambient temperature}

Temperatures recorded at the study site were within 1 to $2^{\circ} \mathrm{C}$ of those at the Pallamana Aerodrome weather station. Temperatures were higher and stable throughout the first period of the experiment, with some cooler days in the second period (Fig. 2). Correlation analyses with behavioural parameters (Table 1) were only significant for mean basking time $\left(\min \mathrm{h}^{-1}\right)$. On days with higher average and maximum daily temperature, lizards basked significantly less (Fig. 3). 


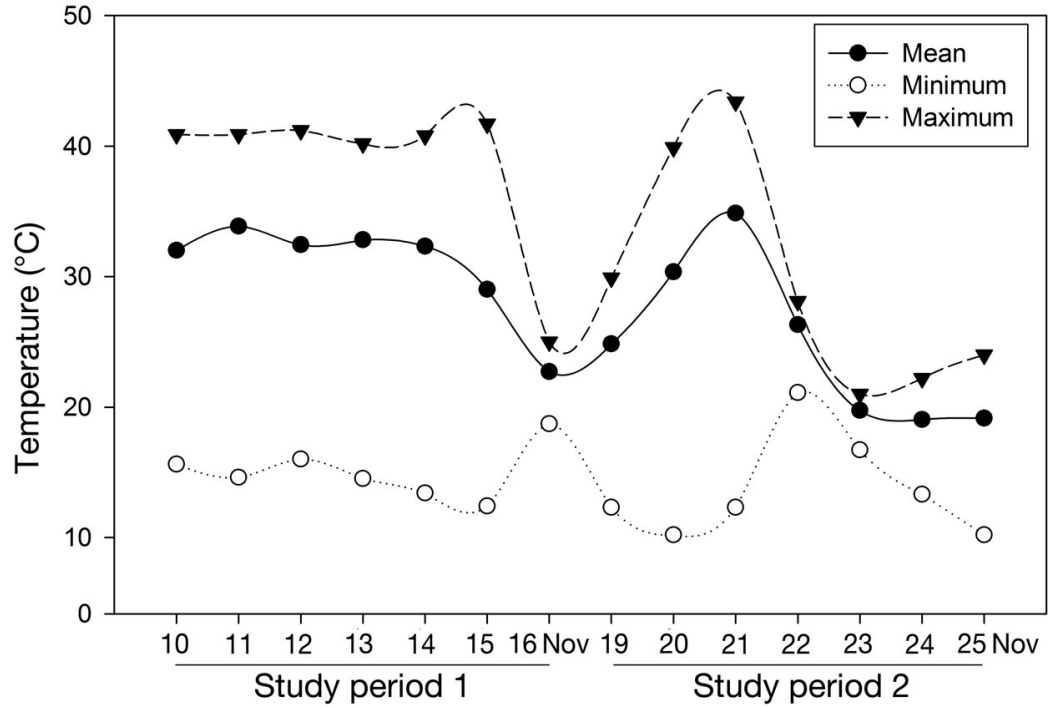

Fig. 2. Mean, maximum and minimum temperature $\left({ }^{\circ} \mathrm{C}\right)$ on each day of filming lizard activity in November 2009

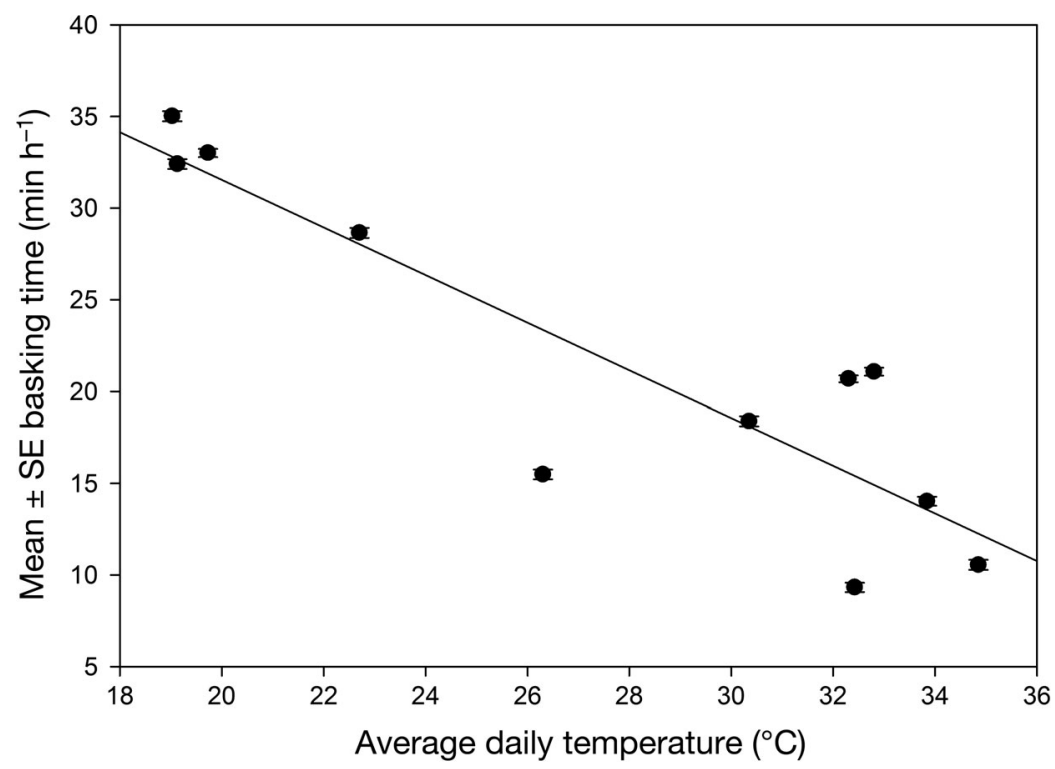

Fig. 3. Tiliqua adelaidensis. Mean \pm SE basking time $\left(\mathrm{min}^{-1}\right)$ and average daily temperature $\left({ }^{\circ} \mathrm{C}\right)$ including data from both fed and unfed treatments. $\mathrm{n}=16$ lizards

\section{Activity time}

The total time that lizards remained active per day varied significantly among days (Table 2), from $<2 \mathrm{~h}$ (food added: Day 7 of Period 1) to $>7 \mathrm{~h}$ (no food added: Day 4 of Period 2, Fig. 4). Although day-to-day variation in ambient conditions probably influenced this variation, activity time was not significantly related (in a linear fashion) to daily temperature (Table 1). In relation to our specific hypothesis, the analysis showed a significant effect of food treatment on activity time (Table 2), with fed lizards remaining active for about $1.5 \mathrm{~h}$ less each day (mean \pm SE daily activity time: fed lizards, $4.04 \pm 0.40 \mathrm{~h}$; unfed lizards, $5.51 \pm 0.53 \mathrm{~h})$. The non-significant food $\times$ day and food $\times$ order interactions (Table 2) suggest that the decreased activity time of fed lizards was consistent across days and across treatment orders. The significant food $x$ day $\times$ order interaction (Table 2) probably results from ambient conditions differing on particular days within each of the feeding periods (e.g. Day 6 in Period 1 was warmer than Day 6 in Period 2; Fig. 2).

\section{Total activity and number of movements}

Food addition significantly reduced the number of activity events for lizards each day by about $40 \%$ (Table 2 ; mean number of daily activity events: fed lizards, $7.78 \pm 0.12$;

Table 1. Tiliqua adelaidensis. Pearson correlation between lizard behavioural parameters and daily average, minimum and maximum temperature. Values in bold are significant at $\mathrm{p}<0.05$. In each case $\mathrm{n}=12 \mathrm{~d}$

\begin{tabular}{|c|c|c|c|c|c|c|c|c|}
\hline Temperature & & $\begin{array}{l}\text { Activity time } \\
\qquad\left(\mathrm{h} \mathrm{d}^{-1}\right)\end{array}$ & $\begin{array}{l}\text { Total activity } \\
\left(\text { no. } \mathrm{d}^{-1}\right)\end{array}$ & $\begin{array}{l}\text { Movements } \\
\quad\left(\text { no. }^{-1}\right)\end{array}$ & $\begin{array}{l}\text { Moves to marginal } \\
\text { area }\left(\text { no. } \mathrm{d}^{-1}\right)\end{array}$ & $\begin{array}{l}\text { No. of burrow } \\
\text { changes (no. } \mathrm{d}^{-1} \text { ) }\end{array}$ & $\begin{array}{l}\text { Basking time } \\
\left(\operatorname{min~}^{-1}\right)\end{array}$ & $\begin{array}{l}\text { Fights } \\
\left(\text { no. } d^{-1}\right)\end{array}$ \\
\hline \multirow{2}{*}{$\begin{array}{l}\text { Daily } \\
\text { average }\end{array}$} & $r$ & -0.234 & -0.476 & -0.131 & -0.225 & -0.138 & -0.679 & 0.265 \\
\hline & $\mathrm{p}$ & 0.464 & 0.118 & 0.686 & 0.482 & 0.668 & 0.015 & 0.405 \\
\hline \multirow{2}{*}{$\begin{array}{l}\text { Daily } \\
\text { minimum }\end{array}$} & $r$ & -0.008 & -0.211 & -0.152 & -0.152 & -0.073 & -0.132 & 0.076 \\
\hline & $\mathrm{p}$ & 0.981 & 0.511 & 0.636 & 0.638 & 0.822 & 0.683 & 0.815 \\
\hline \multirow{2}{*}{$\begin{array}{l}\text { Daily } \\
\text { maximum }\end{array}$} & $r$ & -0.328 & -0.515 & -0.088 & -0.491 & -0.214 & -0.738 & 0.334 \\
\hline & $\mathrm{p}$ & 0.298 & 0.086 & 0.785 & 0.105 & 0.504 & 0.006 & 0.288 \\
\hline
\end{tabular}


Table 2. Tiliqua adelaidensis. Repeated-measure analyses of variance for behavioural parameters in response to the addition of supplementary food. Values in bold indicate significant effects $(\mathrm{p}<0.05)$

\begin{tabular}{|c|c|c|c|c|c|c|c|c|c|c|c|c|c|c|c|c|}
\hline \multirow[t]{2}{*}{ Effect } & \multirow[b]{2}{*}{$\mathrm{df}$} & \multicolumn{2}{|c|}{$\begin{array}{l}\text { Activity time } \\
\qquad\left(\mathrm{h} \mathrm{d}^{-1}\right)\end{array}$} & \multicolumn{2}{|c|}{$\begin{array}{l}\text { Total activity } \\
\left(\text { no. }^{-1}\right)\end{array}$} & \multicolumn{2}{|c|}{$\begin{array}{l}\text { Movements } \\
\quad\left(\text { no. } d^{-1}\right)\end{array}$} & \multicolumn{3}{|c|}{$\begin{array}{c}\text { Moves to marginal } \\
\text { area }\left(\text { no. } \mathrm{d}^{-1}\right)\end{array}$} & \multicolumn{2}{|c|}{$\begin{array}{c}\text { No. of burrow } \\
\text { changes }\left(\text { no. } d^{-1} \text { ) }\right.\end{array}$} & \multicolumn{2}{|c|}{ 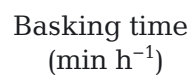 } & \multicolumn{2}{|c|}{$\begin{array}{l}\text { Fights } \\
\left(\text { no. } d^{-1}\right)\end{array}$} \\
\hline & & $F$ & $\mathrm{p}$ & F & $\mathrm{p}$ & $F$ & $\mathrm{p}$ & df & $F$ & $\mathrm{p}$ & $F$ & $\mathrm{p}$ & F & $\mathrm{p}$ & $F$ & $\mathrm{p}$ \\
\hline Food & 1,2 & 20.69 & 0.045 & 18.73 & 0.049 & 4.41 & 0.1717 & 1,14 & 8.86 & 0.010 & 5.16 & 0.039 & 8.22 & 0.012 & 0.19 & 0.664 \\
\hline Day & 5,10 & 7.59 & 0.003 & 3.63 & 0.039 & 2.55 & 0.097 & 5,10 & 0.66 & 0.655 & 1.08 & 0.376 & 7.74 & 0.001 & 4.52 & 0.009 \\
\hline Order & 1,2 & 9.45 & 0.092 & 1.44 & 0.352 & 3.66 & 0.195 & 1,14 & 0.04 & 0.834 & 0.20 & 0.655 & 0.47 & 0.503 & 18.99 & 0.001 \\
\hline Food $\times$ Order & 1,2 & 14.09 & 0.064 & 12.88 & 0.070 & 0.52 & 0.543 & 1,14 & 0.21 & 0.654 & 0.33 & 0.572 & 4.17 & 0.060 & 0.19 & 0.664 \\
\hline Food × Day & 5,10 & 0.89 & 0.522 & 1.25 & 0.355 & 3.54 & 0.042 & 5,10 & 4.47 & 0.001 & 1.36 & 0.248 & 1.11 & 0.359 & 0.87 & 0.502 \\
\hline Day $\times$ Order & 5,10 & 1.24 & 0.358 & 0.95 & 0.488 & 3.29 & 0.052 & 5,10 & 2.64 & 0.030 & 0.38 & 0.856 & 2.44 & 0.042 & 2.83 & 0.022 \\
\hline $\begin{array}{l}\text { Food } \times \text { Day } \\
\times \text { Order }\end{array}$ & 5,10 & 6.31 & 0.007 & 2.95 & 0.068 & 2.90 & 0.071 & 5,10 & 0.81 & 0.543 & 0.90 & 0.481 & 0.70 & 0.624 & 2.17 & 0.066 \\
\hline
\end{tabular}

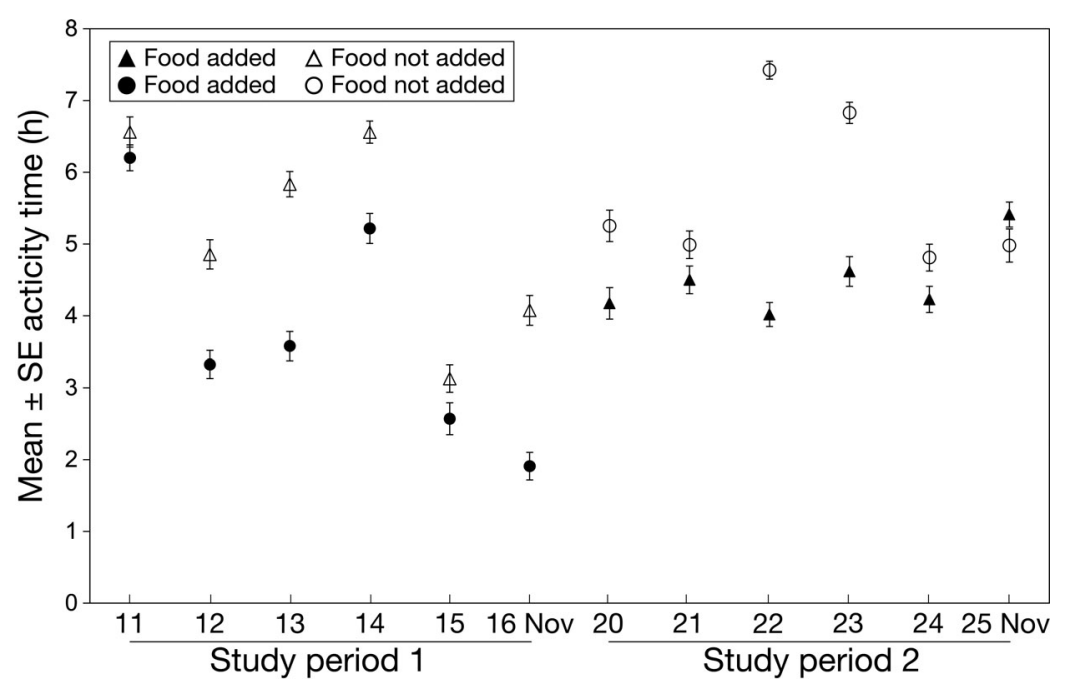

Fig. 4. Tiliqua adelaidensis. Mean \pm SE daily activity time $\left(\mathrm{h} \mathrm{d}^{-1}\right)$ of lizards in each treatment ( $\mathrm{n}=8$ lizards per treatment group). Triangles represent lizards that were unfed in the first week and fed in the second week. Circles represent lizards that were fed in the first week and unfed in the second week made by unfed lizards. The significant food $\times$ day interaction (Table 2) resulted from more moves lizard ${ }^{-1} \mathrm{~d}^{-1}$ to the marginal area by unfed lizards than fed lizards on most, but not all, days. The tendency for supplementary feeding to reduce the number of moves away from the central area became stronger later in the feeding period (Fig. 6). The significant day $\times$ order effect probably again reflects different ambient conditions on specific days within each feeding period.

\section{Burrow changes within the central region}

Of the 182 cases where a lizard changed its burrow within the central region, $121(66.5 \%)$ were by unfed unfed lizards, $13.94 \pm 0.14)$. The difference was consistent across days and treatment orders (no significant food $\times$ day or food $\times$ order interactions, Table 2). The significant effect of day (Table 2) on the number of activity events again probably reflects changing ambient conditions or degrees of lizard satiation over the experimental periods, although we detected no significant linear effect of daily temperature (Table 1).

There was a significant food $\times$ day effect on the mean number of movements lizard ${ }^{-1} \mathrm{~d}^{-1}$ outside of the burrow (Table 2). Fed lizards moved less often than unfed lizards earlier in the food addition period, but the difference between treatments was reduced on the last $2 \mathrm{~d}$ (Fig. 5).

Of the 946 total movements recorded, only 56 were to marginal area burrows, with 37 (66\%) of those lizards. The analysis showed a significant effect of food addition that was consistent across days and presentation order (Table 2). Fed lizards (mean 0.50 \pm 0.010 changes $\mathrm{d}^{-1}$ ) changed burrows significantly less often than unfed lizards (mean $1.125 \pm 0.016$ changes $\mathrm{d}^{-1}$ ).

\section{Basking time and number of fights}

Fed lizards basked at their burrow entrance for significantly shorter times (about 10 min less each hour than unfed lizards: $18.84 \pm 1.10 \mathrm{~min}^{-1}$ versus 28.58 $\pm 1.42 \mathrm{~min}^{-1}$; Table 2). The significant effects of day and the day $x$ order interaction on basking time probably reflect the impact of daily changes in ambient conditions shown previously. 


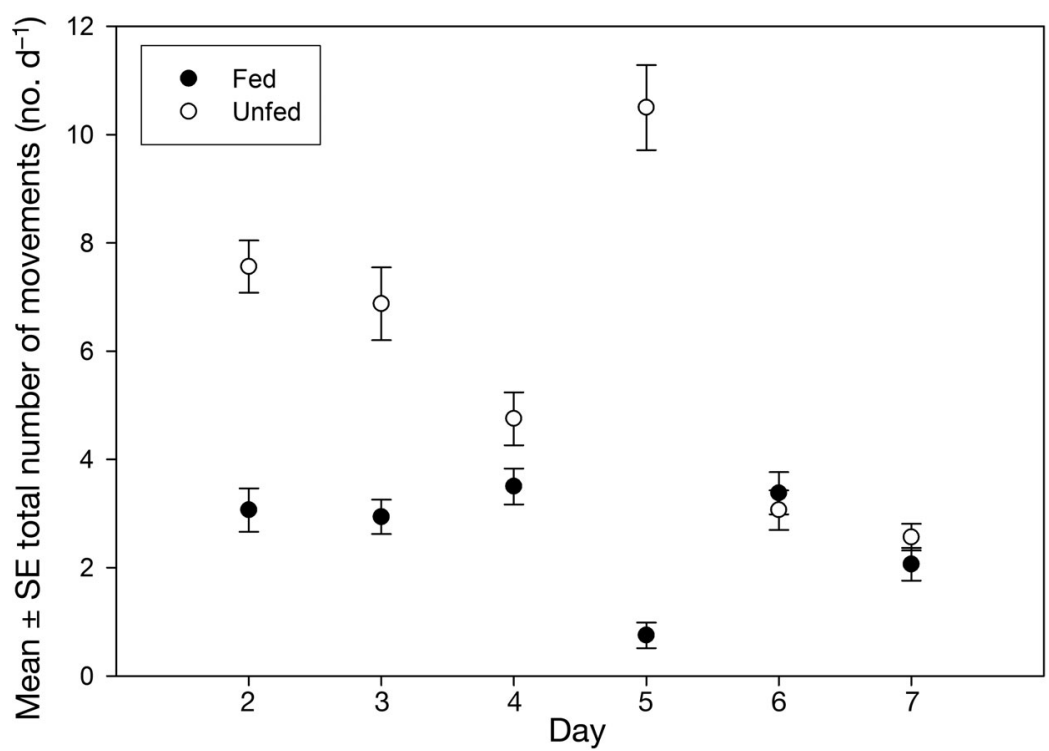

Fig. 5. Tiliqua adelaidensis. Mean \pm SE total number of movements lizard ${ }^{-1} \mathrm{~d}^{-1}$ in fed and unfed groups combining the alternative orders of treatment presentation. $\mathrm{n}=16$ lizards per treatment

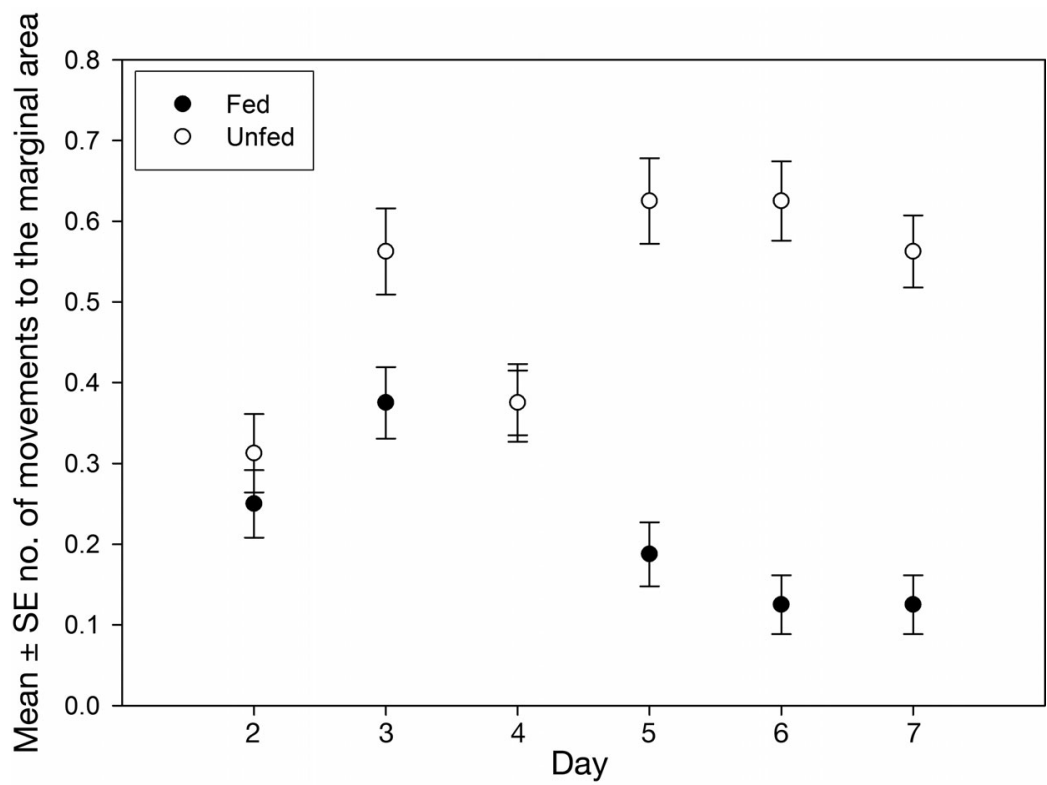

Fig. 6. Tiliqua adelaidensis. Mean \pm SE number of lizards observed in marginal areas per day in fed and unfed groups combining the alternative orders of treatment presentation. $\mathrm{n}=16$ lizards per treatment

Although the mean number of fights lizard ${ }^{-1} \mathrm{~d}^{-1}$ was small, there was a significant interaction effect of day $\times$ order (Table 2). Lizards that were fed and then unfed fought less frequently than lizards that were unfed and then fed, although that difference generally decreased with time (Fig. 7). There was no significant effect involving the feeding treatment.

\section{DISCUSSION}

We detected significant differences between fed and unfed lizards for a number of behavioural parameters, which may have implications for the success of translocation programmes. We also observed strong day-to-day variation in a number of behaviours, probably driven by differences in satiation levels of lizards, or by variation in ambient climatic conditions. We could only detect a linear correlation with daily temperature for 1 parameter, mean time spent basking per hour, with lizards basking for less time when temperatures were higher. This could be explained by the hotter days over the first week of the experiment when the lizards probably needed to shelter in their burrows more often to avoid over-heating.

Fed lizards were consistently less active than unfed lizards, as measured both by the duration of activity during a day, and the number of activity events in a day. These results conform with other studies that have reported higher activity (Abrams 1993, Werner \& Anholt 1993, Anholt \& Werner 1995) and increased predation risk (McNamara 1987, Anholt \& Werner 1995) when resources are scarce. In a translocation, higher activity rates would lead to longer periods of exposure out of burrows, and higher risk of predation in a new location. Additionally, in our system, more active pygmy bluetongue lizards are more likely to disperse from a release site.

In our experiments, adding supplementary food reduced the overall number of moves, the number of times lizards changed burrows in the central release area, and the number of moves out of the central area. We interpret our result to infer that lizards are more likely to seek alternative burrows, or to attempt to move to alternative sites if they perceive that there is a low chance of capturing invertebrate prey from their current burrow. Bright \& Morris (1994) reported that translocated dormice showed a similar reduction in dispersal movements when supplementary food was added, and Ruffell \& 


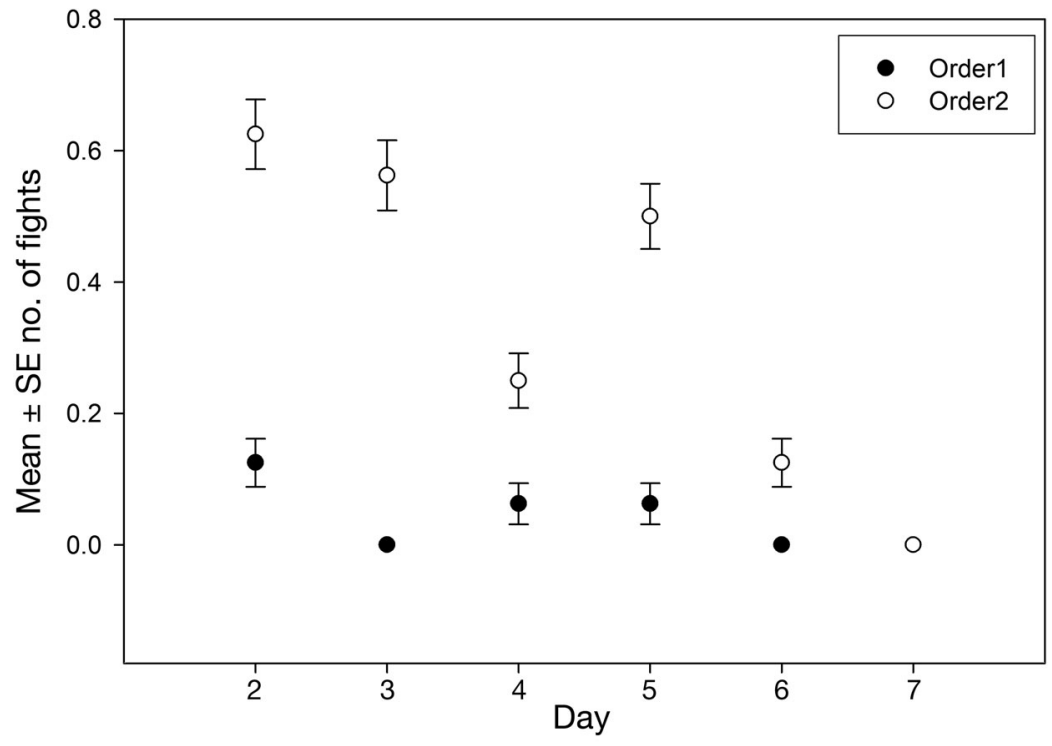

Fig. 7. Tiliqua adelaidensis. Mean \pm SE number of fights lizard ${ }^{-1} \mathrm{~d}^{-1}$ in fed and unfed groups combining the alternative orders of treatment presentation. $\mathrm{n}=$ 16 lizards per treatment

Parsons (2009) reported that translocated bats provided with supplementary food remained at the release site.

When we reversed the treatment conditions and stopped adding supplementary food to 1 group of lizards, they became more active, moved more, and were more likely to disperse out of the central area. Thus, at least for newly translocated lizards, the perception of adequate food supply must be sustained if movements are to be suppressed. For the gopher tortoise, it has been suggested that programmes of supplementary food addition must be sustained for up to $2 \mathrm{yr}$ for the successful establishment of the translocated population (Tuberville et al. 2005, Field et al. 2007).

In our study, adding food also reduced the time lizards spent basking. Basking at the burrow entrance may be both for thermoregulation and for surveillance of passing prey items (Hutchinson et al. 1994, Milne et al. 2003b). The decreased basking time of fed lizards may be related to prey searching, since fed and unfed lizards would have experienced similar thermal conditions. This result also reflects the common observation that satiated animals are less likely to expose themselves to predation risks (McNamara 1987, Werner \& Anholt 1993).

Although agonistic interactions with conspecifics may be an additional stimulus for translocated animals to disperse, our results did not show any overall difference in the incidence of fights between fed or unfed lizards. Therefore, this is unlikely to have been a factor in the dispersal difference we observed. However, on some days we observed those fed in the second week to fight more often than those fed in the first week. This result may reflect higher activity levels and encounter rates between hungrier lizards.

Supplementary feeding is a common management technique used to increase reproductive activity and fecundity in endangered birds in their endemic or translocated sites (Armstrong et al. 1999, 2007, Castro et al. 2003, Schoech et al. 2008), and to enhance fitness of translocated mammals (Licht 1974, Rose 1982, Bright \& Morris 1994, Ruffell \& Parsons 2009). We did not maintain supplementary feeding for a long enough period to explore this possible advantage for translocated lizards. Indeed, our study was not designed to explore the overall impact of food addition on translocation success, but rather to determine whether behaviours related to dispersal from a translocation site were influenced by food supplementation.

However, we have shown that supplementary food can significantly alter some critical components of daily behaviour for lizards that are released into a novel environment. Notably, fed lizards were more likely to reduce their risks of predation and remain closer to their release site. Supplementary feeding may be an important component to improve establishment success for this species at other sites, and may be useful to decrease dispersal from a translocation site in other endangered reptiles.

Acknowledgements. This project was funded by the Australian Research Council, the Holsworth Wildlife Research Endowment Fund, the Sir Mark Mitchell Research Foundation, ZoosSA, the SA Department of the Environment and Natural Resources (DENR), the Field Naturalists Society of SA, the SA Museum, the Northern and Yorke NRM Board and the SA Murray-Darling NRM Board. M.E. was supported by a PhD scholarship from the Ministry of Sciences, Research and Technology of Iran. We thank Monarto Zoo staff, J. Lugg, R. Reuter, I. Smith and D. McLelland for logistical help and M. Ansari for help with the field work. The research was conducted according to the guidelines of Flinders University Animal Welfare Committee (approval no. E206) and under SA DENR Permit (G25011).

\section{LITERATURE CITED}

Abrams PA (1993) Why predation rate should not be proportional to predator density. Ecology 74:726-733 
Anholt BR, Werner EE (1995) Interaction between food availability and predation mortality mediated by adaptive behavior. Ecology 76:2230-2234

Armstrong DP, McLean IG (1995) New Zealand translocations: theory and practice. Pac Conserv Biol 2:39-54

Armstrong DP, Perrott JK (2000) An experiment testing whether condition and survival are limited by food supply in a reintroduced hihi population. Conserv Biol 14: 1171-1181

> Armstrong DP, Castro I, Alley JC, Feenstra B, Perrott JK (1999) Mortality and behaviour of hihi, an endangered New Zealand honeyeater, in the establishment phase following translocation. Biol Conserv 89:329-339

- Armstrong DP, Castro I, Griffiths R (2007) Using adaptive management to determine requirements of re-introduced populations: the case of the New Zealand hihi. J Appl Ecol 44:953-962

- Boutin S (1990) Food supplementation experiments with terrestrial vertebrates: patterns, problems, and the future. Can J Zool 68:203-220

Bright PW, Morris PA (1994) Animal translocation for conservation: performance of dormice in relation to release methods, origin and season. J Appl Ecol 31:699-709

Castro I, Brunton DH, Mason KM, Ebert B, Griffiths R (2003) Life history traits and food supplementation affect productivity in a translocated population of the endangered hihi (stitchbird, Notiomystis cincta). Biol Conserv 114: 271-280

Clout MN, Elliott GP, Robertson BC (2002) Effects of supplementary feeding on the offspring sex ratio of kakapo: a dilemma for the conservation of a polygynous parrot. Biol Conserv 107:13-18

Dodd CK, Seigel RA (1991) Relocation, repatriation, and translocation of amphibians and reptiles: Are they conservation strategies that work? Herpetologica 47: 336-351

Ebenhard T (1995) Conservation breeding as a tool for saving animal species from extinction. Trends Ecol Evol 10: 438-443

Ebrahimi M, Fenner AL, Bull CM (2012) Lizard behaviour suggests a new design for artificial burrows. Wildl Res 39:295-300

> Elliott GP, Merton DV, Jansen PW (2001) Intensive management of a critically endangered species: the kakapo. Biol Conserv 99:121-133

> Fellows HL, Fenner AL, Bull CM (2009) Spiders provide important resources for an endangered lizard. J Zool (Lond) 279:156-163

Fenner AL, Bull CM (2009) Tiliqua adelaidensis (pygmy bluetongue lizard) mating behaviour. Herpetol Rev 40: 91-92

> Fenner AL, Bull CM (2010) The use of scats as social signals in a solitary, endangered scincid lizard, Tiliqua adelaidensis. Wildl Res 37:582-587

> Fenner AL, Bull CM (2011a) Central-place territorial defence in a burrow-dwelling skink: aggressive responses to conspecific models in pygmy bluetongue lizards. J Zool (Lond) 283:45-51

Fenner AL, Bull CM (2011b) Responses of the endangered pygmy bluetongue lizard to conspecific scats. J Ethol 29: 69-77

Fenner AL, Hutchinson MN, Bull CM (2006) Unique tail regeneration in a pygmy bluetongue lizard, Tiliqua adelaidensis. Herpetofauna 36:68-69

Fenner AL, Bull CM, Hutchinson MN (2008a) Injuries to lizards: conservation implications for the endangered pygmy bluetongue lizard (Tiliqua adelaidensis). Wildl Res 35:158-161

Fenner AL, Schofield AJ, Smith AL, Bull CM (2008b) Observations of snake predation on the pygmy bluetongue lizard, Tiliqua adelaidensis. Herpetofauna 38:105-109

Field KJ, Tracy CR, Medica PA, Marlow RW, Corn PS (2007) Return to the wild: translocation as a tool in conservation of the desert tortoise (Gopherus agassizii). Biol Conserv 136:232-245

Fischer J, Lindenmayer DB (2000) An assessment of the published results of animal relocations. Biol Conserv 96: $1-11$

Germano JM, Bishop PJ (2009) Suitability of amphibians and reptiles for translocation. Conserv Biol 23:7-15

Hodder KH, Bullock JM (1997) Translocations of native species in the UK: implications for biodiversity. J Appl Ecol 34:547-565

Hoodless AN, Draycott RAH, Ludiman MN, Robertson PA (1999) Effects of supplementary feeding on territoriality, breeding success and survival of pheasants. J Appl Ecol 36:147-156

Hutchinson MN, Milne T, Croft T (1994) Redescription and ecological notes on the pygmy bluetongue, Tiliqua adelaidensis (Squamata: Scincidae). Trans R Soc S Aust 118: 217-226

IUCN (International Union for Conservation of Nature) (1987) Position statement on translocation of living organisms: introduction, reintroduction and re-stocking. IUCN, Gland

IUCN (1998) Guidelines for re-introductions. Prepared by the IUCN/SSC Re-introduction Specialist Group. IUCN, Gland

Licht P (1974) Response of Anolis lizards to food supplementation in nature. Copeia 1974:215-221

> López-Bao JV, Rodríguez A, Palomares F (2008) Behavioural response of a trophic specialist, the Iberian lynx, to supplementary food: patterns of food use and implications for conservation. Biol Conserv 141:1857-1867

McNamara JM (1987) Starvation and predation as factors limiting population size. Ecology 68:1515-1519

> Milne T, Bull CM, Hutchinson MN (2003a) Fitness of the endangered pygmy blue tongue lizard Tiliqua adelaidensis in artificial burrows. J Herpetol 37:762-765

> Milne T, Bull CM, Hutchinson MN (2003b) Use of burrows by the endangered pygmy blue-tongue lizard, Tiliqua adelaidensis (Scincidae). Wildl Res 30:523-528

> Platenberg RJ, Griffiths RA (1999) Translocation of slowworms (Anguis fragilis) as a mitigation strategy: a case study from south-east England. Biol Conserv 90: 125-132

Robb GN, McDonald RA, Chamberlain DE, Bearhop S (2008) Food for thought: supplementary feeding as a driver of ecological change in avian populations. Front Ecol Environ 6:476-484

> Rose B (1982) Food intake and reproduction in Anolis acutus. Copeia 1982:322-330

Rout T, Hauser CE, Possingham HP (2005) Optimal translocation strategies for threatened species. In: Zerger A, Argent RM (eds) MODSIM05. Modelling and Simulation Society of Australia \& New Zealand, The University of Melbourne, Melbourne, p 2096-2101

Ruffell J, Parsons S (2009) Assessment of the short-term success of a translocation of lesser short-tailed bats Mystacina tuberculata. Endang Species Res 8:33-39 
Schoech SJ, Bridge ES, Boughton RK, Reynolds SJ, Atwell JW, Bowman R (2008) Food supplementation: a tool to increase reproductive output? A case study in the threatened Florida scrub-jay. Biol Conserv 141:162-173

Seddon PJ (1999) Persistence without intervention: assessing success in wildlife reintroductions. Trends Ecol Evol 14:503

Simmons RE (1993) Effects of supplementary food on density-reduced breeding in an African eagle: adaptive restraint or ecological constraint? Ibis 135:394-402

Souter NJ, Bull CM, Hutchinson MN (2004) Adding burrows to enhance a population of the endangered pygmy blue tongue lizard, Tiliqua adelaidensis. Biol Conserv 116: 403-408

Tenhumberg B, Tyre AJ, Shea K, Possingham HP (2004) Linking wild and captive populations to maximize species persistence: optimal translocation strategies. Conserv Biol 18:1304-1314

Editorial responsibility: Mike Thompson,

Sydney, Australia
Towns DR, Ferreira SM (2001) Conservation of New Zealand lizards (Lacertilia: Scincidae) by translocation of small populations. Biol Conserv 98:211-222

> Tuberville TD, Clark EE, Buhlmann KA, Gibbons JW (2005) Translocation as a conservation tool: site fidelity and movement of repatriated gopher tortoises (Gopherus polyphemus). Anim Conserv 8:349-358

van Heezik Y, Maloney RF, Seddon PJ (2009) Movements of translocated captive-bred and released critically endangered kaki (black stilts) Himantopus novaezelandiae and the value of long-term post-release monitoring. Oryx 43: 639-647

Werner EE, Anholt BR (1993) Ecological consequences of the trade-off between growth and mortality rates mediated by foraging activity. Am Nat 142:242-272

Wolf CM, Griffith B, Reed C, Temple SA (1996) Avian and mammalian translocations: update and reanalysis of 1987 survey data. Conserv Biol 10:1142-1154

Submitted: February 7, 2012; Accepted: June 15, 2012

Proofs received from author(s): August 13, 2012 